\title{
The Impact of Pollution Charges, Ash Handling and Carbon Dioxide on the Cost Competitiveness of the Fuel Sources Used for Energy Production in Estonia
}

\author{
Eduard Latisov, Department of Thermal Engineering, Tallinn University of Technology, Juri Kleesmaa, Department \\ of Thermal Engineering, Tallinn University of Technology, Andres Siirde, Department of Thermal Engineering, \\ Tallinn University of Technology
}

\begin{abstract}
The goal of this paper is to estimate the effects of pollution charges, ash handling and of the carbon dioxide quota trade on the competitiveness of natural gas, oil shale, peat and wood chips in Estonia for 2010 and 2015.

The pollution charges and levels are calculated based on the Environmental Charges Act, and Regulations No 99/2004 and No 94/2004 of the Estonian Minister of the Environment.

The calculations show a considerable change in the cost competitiveness of fuels. Fuel related costs of the fossil fuels with high $\mathrm{CO}_{2}$ emission factors and other environmental impacts may be doubled.
\end{abstract}

Keywords - carbon dioxide, cost competitiveness, environmental fees, fuel sources.

\section{INTRODUCTION}

This paper draws on the on-going study 'Analysis on the technical and economic consequences of renewable energy based CHP systems in new areas with the lowered useful heat demand or after implementation of energy conservation measures in the areas with older buildings' within the project 'Primary Energy Efficiency', partly financed by Nordic Energy Research, which contributes to the effort of enhancing the primary energy efficiency (PEE) and reducing $\mathrm{CO}_{2}$ emissions in the energy sector. The objective of the referred study is to create a computer program to estimate the economic and technical feasibility with a view to building a CHP plant based on renewable fuels in the Nordic/Baltic Sea Region countries taking into account local conditions. The novelty of the planned computer program lies in the orientation to the under 10 $\mathrm{MW}_{\mathrm{el}}$ distributed CHP units based on the existing district heating networks.

The goal of the paper is to estimate the effects of pollution charges for emissions, ash handling and of the carbon dioxide quota trade on the competitiveness of different fossil and biofuels in Estonia.

The competitiveness is determined by the comparison of fuel related costs for different energy sources for the years 2010 and 2015. Fuel related costs consist of fuel price, ash handling costs and environmental fees, as well as the carbon dioxide quota price per one MWh of fuel energy content (based on lower calorific value).

The paper is structured as follows: Section II describes the procedure and methods for determining the emissions of pollutants from combustion plants into ambient air. Then, after an overview of pollution charge rates, the pollution charge rates per one MWh of fuel energy content are calculated. The next section describes the ash handling costs of the observed fuels. Section VI provides calculations of the $\mathrm{CO}_{2}$ quota amount level per one MWh. Section VII provides calculation and analysis of the impacts of pollution fees, ash handling and carbon dioxide costs (environmental costs) on the competitiveness of fuel costs, as well as an analysis of the fuel-related costs of different energy sources for the years 2010 and 2015 .

The last section provides conclusions and proposals based on the calculation results and data set out in previous sections.

\section{II.PROCEDURE AND METHODS FOR DETERMINING EMISSIONS OF POLLUTANTS FROM COMBUSTION PLANTS INTO AMBIENT AIR}

Regarding [1], emissions of sulphur dioxide, nitrogen oxides, carbon oxide, volatile organic compounds, solid particles and heavy metals generated by combustion plants and emitted into ambient air shall be determined on the basis of direct measurements and/or calculations. In this paper the determination of emissions of pollutants is based on calculations. This method takes into account different combustion technologies, flue gas cleaning technologies, control devices as well as capacities to define the emission factors of pollutants.

To avoid the complexity of analysis arising from different combinations of capacities, combustion technologies, fuel gas cleaning and control equipment, it is assumed that:

- the thermal capacity of combustion plants is below 50 MW;

- the selected combustion technology provides the lowest emission level compared to all other combustion technologies mentioned in [1];

- the combustion plant is equipped with the most effective control systems mentioned in [1];

- the combustion plant is equipped with the most effective flue gas treatment technology mentioned in [1]. 
Emissions of carbon dioxide are calculated according to the method described in [2], thereby the carbon dioxide emissions from biofuels equal zero.

Emission factors in kilograms per one MWh of fuel energy content are calculated based on the methods described in the above-mentioned regulations and assumptions. Calculation results are shown in Table I.

TABLE I

EMISSION FACTORS IN TONS PER ONE MWh OF FUEL ENERGY CONTENT

\begin{tabular}{|c|c|c|c|c|}
\hline \multirow[b]{2}{*}{ POLLUTANT } & \multicolumn{4}{|l|}{ FUELS } \\
\hline & Oil shale & Peat & $\begin{array}{l}\text { Natural } \\
\text { gas }\end{array}$ & $\begin{array}{l}\text { Wood } \\
\text { chips }\end{array}$ \\
\hline Carbon dioxide, $\mathrm{CO}_{2}{ }^{1}$ & 360 & 374 & 201 & 0 \\
\hline Sulphur dioxide, $\mathrm{SO}_{2}$ & 13.0 & 0.72 & 0 & 0 \\
\hline Nitrogen oxides, $\mathrm{NO}_{\mathrm{x}}$ & 0.54 & 1.08 & 0.22 & 0.36 \\
\hline Carbon monoxide, $\mathrm{CO}$ & 0.36 & 0.36 & 0.14 & 0.72 \\
\hline Particulates $^{2}$ & 3.60 & 0.29 & 0 & 0.25 \\
\hline $\begin{array}{l}\text { Volatile organic } \\
\text { compounds }^{3}\end{array}$ & 4.32 & 0.36 & 0.014 & 0.17 \\
\hline Heavy metals & 0.0039 & 0.00028 & 0.00 & 0.000104 \\
\hline
\end{tabular}

${ }^{1}-\mathrm{kg} / \mathrm{MWh}_{\text {fuel }}$

${ }^{2}$ - except for heavy metals and compounds of heavy metals.

3 - except for mercaptans.

\section{POLLUTION CHARGE RATES}

Pollution charge rates upon emission of pollutants into ambient air are defined in [3]. Charge rates are given until the year 2015. The pollution charges per one ton of pollutant for the years 2010 and 2015 are shown in Table II.
POLLUTION CHARGE RATES PER ONE TON OF POLLUTANT

\begin{tabular}{|c|c|c|}
\hline \multirow[b]{2}{*}{ POLLUTANT } & \multicolumn{2}{|c|}{ EUR/t } \\
\hline & 2010 & 2015 \\
\hline Carbon dioxide, $\mathrm{CO}_{2}$ & 2.0 & 2.0 \\
\hline Sulphur dioxide, $\mathrm{SO}_{2}$ & 39.4 & 145.46 \\
\hline Nitrogen oxides, $\mathrm{NO}_{\mathrm{x}}$ & 76.4 & 122.32 \\
\hline Carbon monoxide, $\mathrm{CO}$ & 4.8 & 7.7 \\
\hline Particulates $^{1}$ & 39.4 & 146.16 \\
\hline $\begin{array}{l}\text { Volatile organic } \\
\text { compounds }^{2}\end{array}$ & 76.4 & 122.32 \\
\hline Heavy metals & 1216 & 1278 \\
\hline
\end{tabular}

${ }^{1}$ - except for heavy metals and compounds of heavy metals.

${ }^{2}$ - except for mercaptans.

As shown in Table II above, the pollution charges for the year 2015 in comparison to the year 2010 will increase by approximately three and a half times for particulates and sulphur dioxide emissions. A 1.5-fold increase is estimated for nitrogen oxides, carbon monoxide and volatile organic compounds. The pollution charge rates for carbon dioxide and heavy metals will remain on the same level.

\section{POLLUTION CHARGE RATES PER ONE MWh OF FUEL ENERGY CONTENT}

The calculation of pollution charge rates per one MWh of fuel energy content is based on the previously calculated data set out in Sections II and III which describe the emission factors per one MWh of fuel energy content and the pollution charge rates, respectively. The results of calculations are shown in Table III.

TABLE II

TABLE III

POLLUTION CHARGE RATES IN EUR PER ONE MWh OF FUEL ENERGY CONTENT

\begin{tabular}{|c|c|c|c|c|c|c|c|c|}
\hline \multirow{3}{*}{ POLLUTANT } & \multicolumn{8}{|l|}{ FUELS } \\
\hline & \multicolumn{2}{|c|}{ Oil shale } & \multicolumn{2}{|l|}{ Peat } & \multicolumn{2}{|c|}{ Natural gas } & \multicolumn{2}{|c|}{ Wood chips } \\
\hline & 2010 & 2015 & 2010 & 2015 & 2010 & 2015 & 2010 & 2015 \\
\hline Carbon dioxide & 0.72 & 0.72 & 0.75 & 0.75 & 0.40 & 0.40 & 0 & 0 \\
\hline Sulphur dioxide & 0.51 & 1.90 & 0.028 & 0.10 & 0 & 0 & 0 & 0 \\
\hline Nitrogen oxides & 0.04 & 0.07 & 0.082 & 0.13 & 0.016 & 0.026 & 0.027 & 0.044 \\
\hline Carbon monoxide & 0.0017 & 0.0028 & 0.0017 & 0.0028 & 0.0007 & 0.0011 & 0.0034 & 0.0055 \\
\hline Particulates $^{1}$ & 0.14 & 0.53 & 0.011 & 0.04 & 0 & 0 & 0.010 & 0.037 \\
\hline $\begin{array}{l}\text { Volatile organic } \\
\text { compounds }^{2}\end{array}$ & 0.33 & 0.53 & 0.027 & 0.04 & 0.0011 & 0.0018 & 0.013 & 0.021 \\
\hline Heavy metals & 0.0048 & 0.0050 & 0.00034 & 0.00036 & 0 & 0 & 0.00013 & 0.00013 \\
\hline$\underline{\text { Total }}$ & $\underline{1.75}$ & $\underline{\underline{3.75}}$ & $\underline{0.90}$ & $\underline{1.07}$ & $\underline{0.42}$ & $\underline{0.43}$ & $\underline{0.054}$ & $\underline{0.11}$ \\
\hline
\end{tabular}

${ }^{1}$ - except for heavy metals and compounds of heavy metals.

${ }^{2}$ - except for mercaptans.

Table III shows that, at the present time, oil shale has the highest pollution charge rate per one MWh of fuel energy content. Combustion of oil shale implies pollution charges at the rate of about $1.75 \mathrm{EUR} / \mathrm{MWh}_{\text {fuel }}$. Due to high emission factors, especially for sulphur dioxide, carbon dioxide and particulates, the expected pollution charge rate of oil shale will be twice as high and amount to about 3.75 EUR/MWh fuel $_{\text {by } 2015 .}$

The pollution charge rates of peat per one MWh of fuel energy content are estimated to be at the rate of 0.9 and 
$1.07 \mathrm{EUR} / \mathrm{MWh}_{\text {fuel }}$ for the years 2010 and 2015, respectively.

Natural gas has the lowest pollution charge rate per one MWh of fuel energy content in comparison to other fossil fuels observed. The total charge rate is formed mainly of carbon dioxide emissions which make up $95 \%$ of the total. Due to a stable carbon dioxide charge rate for the years 2010 and 2015, the increase in the overall pollution charges is negligible. Pollution charge rates per one MWh of fuel energy content are estimated to be at the rate of 0.42 and $0.43 \mathrm{EUR} / \mathrm{MWh} \mathrm{fuel}_{\text {fue }}$, respectively.

The approved pollution charge rates applied until 2010 and the emission factors determine the wood chips' pollution charge rate per one MWh of fuel energy content to rise by approximately two times. In spite of a relative increase, the total estimated charge rate per one MWh of fuel energy content will be four times lower compared to natural gas, ten times lower compared to peat and 37 times lower compared to oil shale in 2015. Charge rates will comprise 0.11 EUR per one MWh of fuel energy content.

\section{ASH HANDLING}

Ash handling costs for the fuels described in this paper depend on:

- fuel ash content;

- percentage of ash to be handled by the ash removing system;

- water content in ash which determines the final weight of ash to be disposed of.

In the case of wet ash removing technology, the wet ash density is much higher than in the case of implementing the dry ash removing technology (ash removal costs are higher). Unburned fuel particles in ash can cause fire in landfill or in other ash storage place. If ash is wet (removed by wet ash removal technology) then the self ignition risks are significantly reduced. Besides, in the case of wet ash removal, there is no dust in the air and ash is always cold - that contributes to a longer service life of the equipment.

The ash handling cost calculations are based on the following assumptions.

- Regarding the information obtained from the oil shale mining company Eesti Energia Kaevandused Ltd., the average ash content of oil shale is $45 \%$ and the average calorific value of energy oil shale is $2.3 \mathrm{MWh} / \mathrm{t}$.

- The ash content of peat is $5 \%$. The average calorific value is $3.3 \mathrm{MWh} / \mathrm{t}$. [4]

- The ash content of wood chips is $1 \%$ with the calorific value being $2.4 \mathrm{MWh} / \mathrm{t}$.

- Natural gas based combustion does not emit any ash.

- Regarding the information obtained from different landfill owners, the average ash removal costs (ash transportation to a landfill and storing) is $45 \mathrm{EUR} / \mathrm{t}$ for the year 2010 .
- The average ash removal costs will be 65 $\mathrm{EUR} / \mathrm{t}$ in 2015.

- The combustion plant is equipped with the dry ash removing system.

The ash handling costs per one MWh of fuel energy content for the years 2010 and 2015 have been calculated on the basis of the above-mentioned information. The results are shown in Table IV.

\section{TABLE IV}

ASH HANDLING COSTS IN EUR PER ONE MWh OF FUEL ENERGY CONTENT FOR THE YEARS 2010 AND 2015

\begin{tabular}{|l|l|l|}
\hline \multirow{2}{*}{ FUELS } & \multicolumn{2}{|l|}{ YEAR } \\
\cline { 2 - 3 } & $\mathbf{2 0 1 0}$ & $\mathbf{2 0 1 5}$ \\
\hline Oil shale & 8.8 & 12.7 \\
\hline Peat & 0.68 & 0.98 \\
\hline Wood chips & 0.19 & 0.27 \\
\hline Natural gas & 0 & 0 \\
\hline
\end{tabular}

\section{CARBON DIOXIDE QUOTA}

The $\mathrm{CO}_{2}$ quota trade is a symbiosis of power engineering and the financial world, which is important for all energy producers and other industries involved in the quota trade.

In the current situation, the $\mathrm{CO}_{2}$ quota trade rules assume that a combustion plant is not obliged to buy or sell $\mathrm{CO}_{2}$ quotas if the $\mathrm{CO}_{2}$ emissions do not exceed the allocated quantity.

Since the quota trade rules for phase III which will apply after the year 2012 are not yet distinctly clear, it is quite complicated to forecast the $\mathrm{CO}_{2}$ quota price. In general, phase III means a cancellation or a significant reduction in the $\mathrm{CO}_{2}$ quotas allocated to EU countries and putting into operation a general exchange for trading in $\mathrm{CO}_{2}$ quotas.

Regarding [5], if $\mathrm{CO}_{2}$ trading will be prolonged after 2012 , the $\mathrm{CO}_{2}$ quota price level could be in the range of 20 to $35 \mathrm{EUR} / \mathrm{t}$.

The $\mathrm{CO}_{2}$ quota amount levels per one $\mathrm{MWh}$ of fuel energy content are calculated and shown in Table V.

TABLE V

THE $\mathrm{CO}_{2}$ QUOTA AMOUNT LEVELS PER ONE MWh OF FUEL ENERGY CONTENT

\begin{tabular}{|l|l|l|}
\hline \multirow{2}{*}{ FUELS } & \multicolumn{2}{|l|}{$\mathrm{CO}_{2}$ QUOTA PRICE } \\
\cline { 2 - 3 } & 20 EUR/t & 35 EUR/t \\
\hline Oil shale & 7.2 & 12.6 \\
\hline Peat & 7.5 & 13.1 \\
\hline Natural gas & 4.0 & 7.0 \\
\hline Wood chips & 0 & 0 \\
\hline
\end{tabular}

The $\mathrm{CO}_{2}$ quota amount level per one $\mathrm{MWh}$ is proportional to a fuel-specific $\mathrm{CO}_{2}$ emission factor. Thus the $\mathrm{CO}_{2}$ quota amount level per one MWh of oil shale or peat is almost twice as high as the respective value of natural gas. 


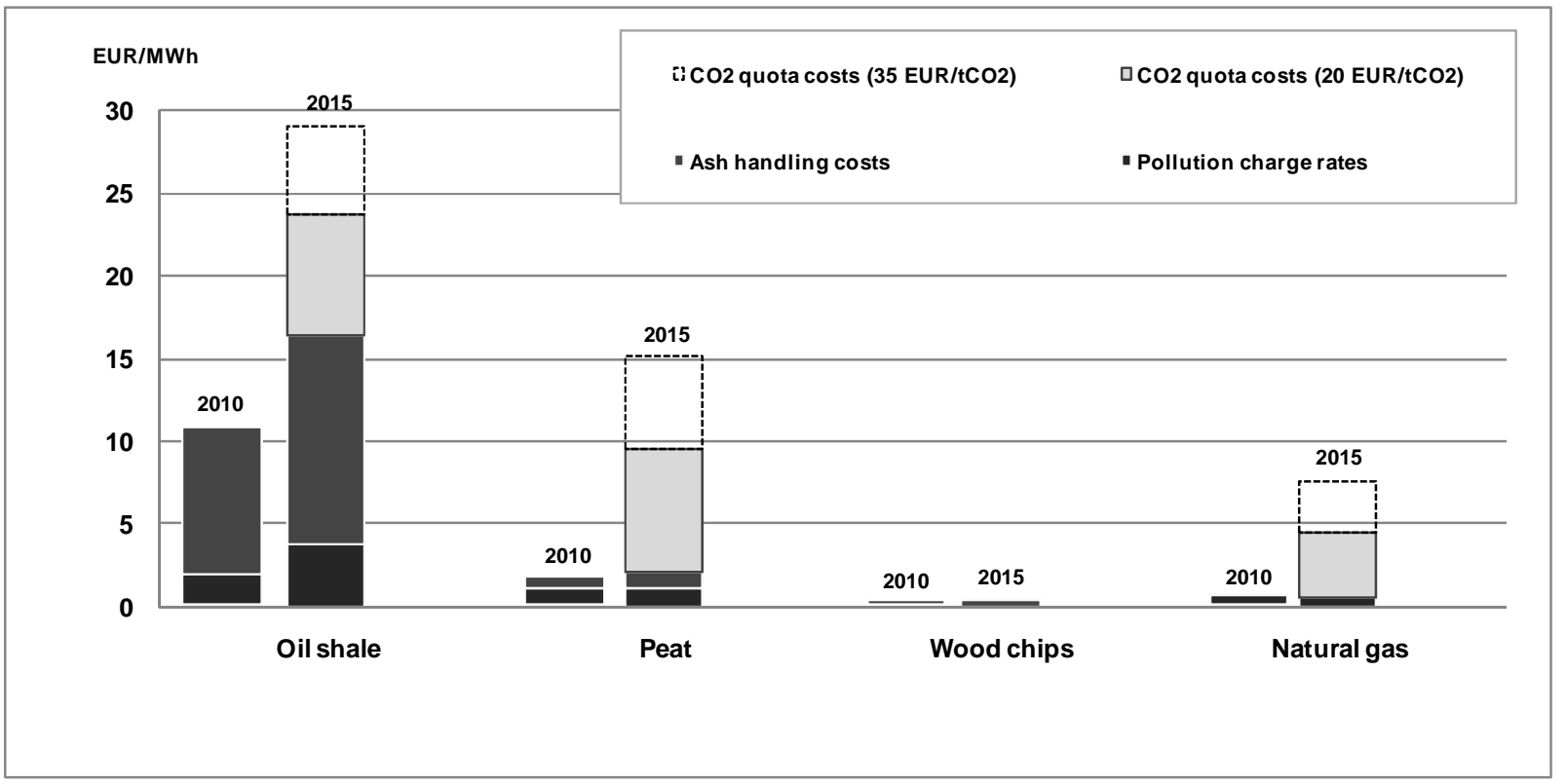

Fig. 1. Environmental costs per one MWh of fuel energy content for the years 2010 and 2015.

\section{IMPACT OF POLLUTION FEE, ASH HANDLING AND CARBON DIOXIDE COSTS (ENVIRONMENTAL COSTS) ON THE FUEL COST COMPETITIVENESS}

\section{A. Environmental costs for the years 2010 and 2015}

The costs per one MWh of fuel energy content for the years 2010 and 2015 described in Sections IV, V and VI are summarized in Fig. 1.

Oil shale has the highest environmental costs (10.6 EUR/MWhfuel) in 2010 as well as the largest absolute increase in the costs per one MWh of fuel energy content for 2015. The increase will comprise 13.1-18.5 EUR/MWh fuel depending on the assumed $\mathrm{CO}_{2}$ quota price scenarios.

The environmental costs of peat and wood chips for the year 2010 are estimated to be below $2 \mathrm{EUR} / \mathrm{MWh}_{\text {fuel }}$. The environmental costs of wood chips will change insignificantly by 2015 . At the same time, due to a high carbon dioxide emission factor, the environmental costs of peat will be 5-8.5 times higher and amount to $9.5-15.1 \mathrm{EUR} / \mathrm{MWh}_{\text {fuel }}$.

In spite of a relative 10-18-fold increase in the environmental costs of natural gas from $0.4 \mathrm{EUR} / \mathrm{MWh}_{\text {fuel }}$ to

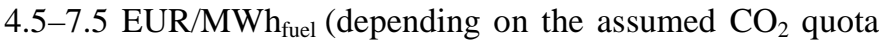
price scenarios), the environmental costs for the years 2010 and 2015 as well as the absolute increase in environmental costs are the lowest in comparison to other fossil fuels observed.

\section{B. Effect of environmental costs on the fuel related costs per one MWh of fuel energy content}

Fuel related costs contain both the fuel purchase costs (fuel price) and the environmental costs, which were considered in the previous section.
The comparison of fuel related costs for the years 2010 and 2015 enables one to forecast the general trends in fuel competitiveness for the near future.

The comparison is based on the assumption that the fuel price is stable. The change in fuel related costs is induced by environmental costs.

The fuel prices taken as a basis for the calculations are as follows:

- Price of oil shale - 4.6 EUR/MWh $\mathrm{Muel}_{\text {fue }}$ The proposed price is the current average purchasing price for one of the Estonian largest oil shale consumers Eesti Energia AS [6].

- Price of peat - 11.7 EUR/MWh $\mathrm{Muel}_{\text {fu }}$ The proposed price is based on the average peat price levels obtained from Tootsi Turvas AS, the biggest peat milling and exporting enterprise in Estonia.

- Price of wood chips - 12.8 EUR/MWh fuel. $_{\text {The proposed }}$ price is based on the latest data published by the Estonian Institute of Economic Research in their web based price information system [7].

- Natural gas - $28 \mathrm{EUR} / \mathrm{MWh}_{\text {fuel }}$. The proposed price is an average price of the latest data published by Statistics Estonia [8].

The calculation results are presented in Table VI as well as shown in Fig. 2.

The calculation results reveal that the proposed increase in environmental costs will change the alignment of forces in the cost competitiveness of fuel sources considerably.

At present, peat is considered a good alternative to wood chips as peat has a lower fuel price compared with the ash handling costs and pollution charges of wood chips. By the year 2015, the use of peat will cause an increase in fuel costs by half up to two times higher per one MWh of fuel energy content, while the fuel costs of wood chips will change insignificantly. 
TABLE VI

FUEL RELATED COSTS IN EUR PER ONE MWh OF FUEL ENERGY CONTENT FOR THE YEARS 2010 AND 2015

\begin{tabular}{|c|c|c|c|c|c|c|c|c|c|}
\hline \multirow[t]{3}{*}{ FUELS } & \multicolumn{3}{|l|}{ YEAR 2010} & \multicolumn{4}{|l|}{ YEAR 2015} & \multirow{2}{*}{\multicolumn{2}{|c|}{$\begin{array}{l}\text { Increase of fuel related costs } \\
\text { from year } 2010 \text { to } 2015\end{array}$}} \\
\hline & \multirow[t]{2}{*}{ Fuel price } & \multirow{2}{*}{$\begin{array}{l}\text { Environmental } \\
\text { costs }\end{array}$} & \multirow{2}{*}{$\begin{array}{l}\text { Fuel related } \\
\text { costs }\end{array}$} & \multirow[t]{2}{*}{ Fuel price } & \multicolumn{2}{|c|}{ Environmental costs } & \multirow{2}{*}{$\begin{array}{l}\text { Fuel related } \\
\text { costs }\end{array}$} & & \\
\hline & & & & & $\begin{array}{l}\text { 20EUR/tCO2 } \\
\text { scenario }\end{array}$ & $\begin{array}{l}35 \text { EUR/tCO2 } \\
\text { scenario }\end{array}$ & & \begin{tabular}{|l} 
Absolute \\
increase
\end{tabular} & \begin{tabular}{|l} 
Relative \\
increase, \%
\end{tabular} \\
\hline Oil shale & 4.6 & 10.6 & 15.2 & 4.6 & 23.7 & 29.1 & 28.3-33.7 & $13.1-18.5$ & $86.5-122.3$ \\
\hline Peat & 11.7 & 1.6 & 13.3 & 11.7 & 9.5 & 15.1 & $21.2-26.8$ & $8-13.5$ & 59.9-101.8 \\
\hline Wood chips & 12.8 & 0.24 & 13.0 & 12.8 & 0.4 & 0.4 & 13.2 & 0.1 & 1.05 \\
\hline Natural gas & 28 & 0.42 & 28.4 & 28 & 4.5 & 7.5 & $32.5-35.5$ & $4-7.1$ & $14.2-24.9$ \\
\hline
\end{tabular}

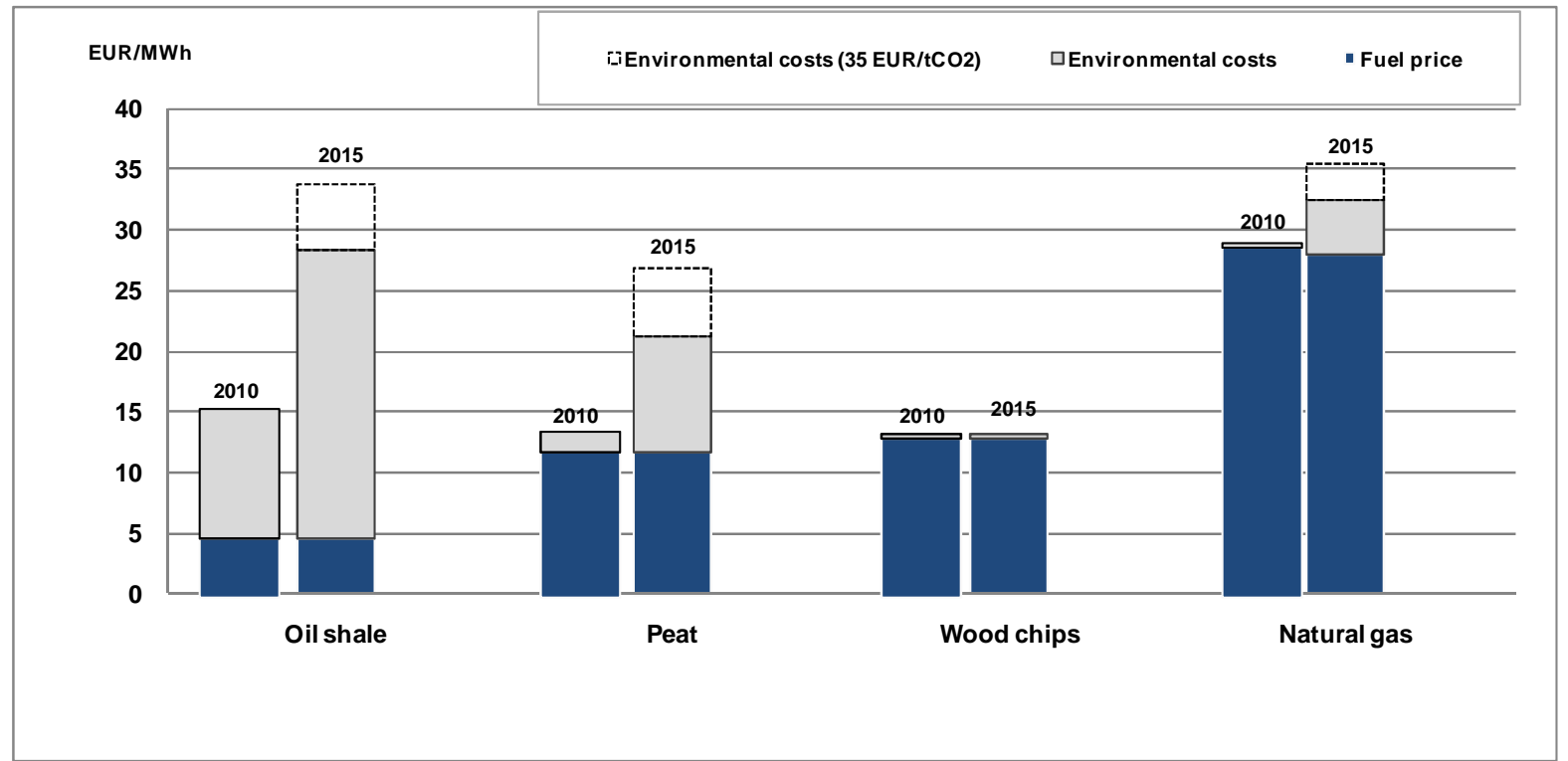

Fig. 2. Fuel related costs per one MWh of fuel energy content for the years 2010 and 2015.

Currently, the fuel related costs of oil shale are almost twice as low as those of natural gas. Due to a larger share of environmental costs in the fuel related costs, as well as due to a 1.8 times higher $\mathrm{CO}_{2}$ emission factor, a significant increase in the fuel related costs can be expected. By the year 2015, the difference in the fuel related costs between oil shale and natural gas will decrease and account for 5-15\% depending on the proposed $\mathrm{CO}_{2}$ quota price scenarios.

\section{CONCLUSION}

The paper observes the impact of pollution charges, ash handling and carbon dioxide on the cost competitiveness of the fuel sources used for energy production in Estonia. Fuel related costs for different energy sources for the years 2010 and 2015 are calculated with respect to the cases when the fuel related costs consist of fuel price, ash handling costs and environmental fees as well as the carbon dioxide quota price per one MWh of fuel energy content (based on lower calorific value). Calculations are provided based on different assumptions of combustion technologies, flue gas cleaning technologies, control devices, ash handling systems and other data. Thereby, calculation results are valid for the reviewed cases only. Other particular cases should be calculated individually.
Calculation results show that the proposed increase in environmental costs will considerably change the alignment of forces in the cost competitiveness of fuel sources by the year 2015.

Oil shale has a higher pollution charge rate per one MWh of fuel energy content. Combustion of oil shale implies pollution charges at the rate of about $1.75 \mathrm{EUR} / \mathrm{MWh}_{\text {fuel }}$. Due to high emission factors, especially for sulphur dioxide, carbon dioxide and particulates, the expected pollution charge rate by 2015 will be twice as high and amount to about $3.75 \mathrm{EUR} \mathrm{MWh}_{\text {fuel }}$. Oil shale has the highest total environmental costs (10.6 EUR/MWh fuel $)$ for 2010 as well as a higher absolute increase of costs per one MWh of fuel energy content for 2015. The increase comprises 13.1-18.5 EUR/MWh $\mathrm{Huel}_{\text {fepending on the assumed }}$ $\mathrm{CO}_{2}$ quota price scenarios. Due to a larger share of environmental costs in the fuel related costs, a significant (87-122\%) growth in the fuel related costs can be expected. This could be crucial to the competitiveness of the oil shale energy production sector in comparison with other fossil and renewable fuels.

Peat. At present, peat is considered a good alternative to wood chips. The lower fuel price of peat (11.7 EUR/MWh the higher fuel price of wood chips (12.8 EUR/MWh $\mathrm{Muel}_{\text {ful }}$, balances the higher environmental taxes (ash handling costs and pollution 
charges) of peat compared to the lower ash handling costs and pollution charges of woodchips.

By the year 2015, the use of peat will cause an increase in fuel costs per one MWh of fuel energy content in a range from a half up to two times (from 13.3 EUR/MWh to 21.2-26.8 $E U R / M W h_{\text {fuel }}$ ), while the fuel costs of wood chips will change insignificantly

Natural gas has low pollution charge rates per one MWh of fuel energy content comprising 0.42 and $0.43 \mathrm{EUR} \mathrm{MWh}_{\text {fuel }}$ for the years 2010 and 2015, respectively. Ash handling costs equal zero in case of natural gas as it does not emit any ash.

Natural gas has a high fuel price which causes the total fuel related costs to be high, too. But with the carbon dioxide emission factor and other environmental costs being relatively low, natural gas can reduce its difference in fuel related costs compared to other fossil fuels which have a higher carbon dioxide emission factor and other environmental impacts. For example, in the case of oil shale, the difference in fuel related costs is estimated to decrease from about $90 \%$ in 2010 to $5-15 \%$ in 2015 , depending on the proposed $\mathrm{CO}_{2}$ quota price scenarios.

Wood chips. The lowest pollution fee costs among the considered fuels $\left(0.054-0.11 \mathrm{EUR} / \mathrm{MWh}_{\text {fuel }}\right.$ for the years 2010 and 2015), a zero for the carbon dioxide emission level as well as the lowest ash handling costs $\left(0.19-0.27\right.$ EUR/MWh fuel $\left._{\text {f }}\right)$ among other considered solid fuels allow to successfully keep the increase in the environmental and total fuel related costs small (13 and 13.2 EUR/MWh fuel for the years 2010 and 2015, respectively). The aforesaid factors significantly improve the competitiveness of wood chips and provide opportunities to expand the wood chips based energy production.

\section{REFERENCES}

1. Procedure and Methods for Determining Emissions of Pollutants from Combustion Plants into Ambient Air (2010.15.06) http://www.riigiteataja.ee/ert/act.jsp?id=789462.

2. Välisõhku eralduva süsinikdioksiidi heitkoguse määramismeetod (2010.15.06) http://www.riigiteataja.ee/ert/act.jsp?id=12757215.

3. Environmental Charges Act (2010.15.06) http://www.riigiteataja.ee/ert/act.jsp?id=13316043.

4. Paappanen T., Leinonen A. Fuel peat industry in EU, 2005, p.134 (2010.15.06) http://www.turbaliit.ee/index.php?picfile=21 .

5. Engebretsen J., Flemming GN. Relationship between $\mathrm{CO} 2$, fuel and electricity prices and the effort on Green House Gas $(G H G)$ emissions in Nordic countries. Copenhagen: Ekspressen Tryk\& Kopicenter, 2008. 108 p.

6. Eesti Energia AS (2010.15.06) www://www.energia.ee/.

7. Estonian Institute of Economic Research (2010.15.06) http://www.ki.ee/.

8. Statistics Estonia (2010.15.06) www.stat.ee.

Eduard Latisov, M.Sc., Researcher

Department of Thermal Engineering, Tallinn University of Technology

Address: Ehitajate tee 5, 19086, Tallinn, Estonia

Phone: +372 53359298

E-mail: eduard.latosov@afconsult.com

Juri Kleesmaa, PhD Student

Tallinn School of Economics and Business Administration

Tallinn University of Technology

Address: Akadeemia tee 3

12618 Tallinn, Estonia

Phone: (+372) 620 3945, Fax: (+372) 6203946

e-mail: pentagra@datanet.ee

Andres Siirde, Dr.Sc.Ing., Professor

Department of Thermal Engineering, Tallinn University of Technology

Address: Kopli 116, 11712 Tallinn, Estonia

Phone: 372+620 3900, Fax: 372+620 3901

e-mail: asiirde@sti.ttu.ee

\begin{abstract}
Eduards Latišovs, Jiri Kleesmaa, Andres Siirde. Dabas resursu nodoḳ̣a, pelnu apstrādes izmaksas un ogleḳ̣a dioksīda kvotu ietekme uz kurināmā konkurētspēju enerğijas ražošanai Igaunijā

Pētỉjuma mērḳis ir novērtêt, kā nodoklis par piesārņojošo vielu emisijām, pelnu apstrādes izmaksas un oglekḷa dioksīda kvotu tirdzniecība (vides izmaksas) ietekmē dabas gāzes, degslānekḷa, kūdras (velēnas kūdra) un koksnes šḳeldas konkurētspēju Igaunijā 2010 un 2015. gadā. Nodoklis par piesārṇojošo vielu emisijām aprēkināts balstoties uz Dabas resursu nodokḷa likumu. Piesārṇojošo vielu izmešu apjomi no dažādiem kurināmā veidiem noteikti, pamatojoties uz Igaunijas Vides ministrijas regulām Nr. 99/2004 un $\mathrm{Nr}$ 94/2004.

Aprēḳinu rezultāti liecina, ka paredzamais ar vides aizsardzību saistītais izmaksu pieaugums jau 2015. gadā var ievērojami mainīt dažādu kurināmo konkurētspēju un to proporciju tirgū. Sakarā ar vides aizsardzỉbas politikas radīto izmaksu pieaugumu, degvielas pašizmaksa (degvielas cenas un vides izmaksu summa uz vienu MWh degvielas ar samazinātu enerǵētisko lietderỉbu) degslānekḷa gadījumā ievērojami pieaugs (līdz pat divas reizes). Tas varētu būt izškirošs faktors degslānekḷa turpmākai konkurētspējai, salīdzinot ar citiem fosilās enerǵijas un atjaunojamajiem enerǵijas avotiem. Pašlaik kūdra ir uzskatāma par labu alternatīvu koksnes šķeldai. Zemāko kūdras cenu (11,7 EUR / MWh kuriāmāa) pret augstāko koksnes šķeldas cenu (12,8 EUR / MWh kurināmā) līidzsvaro augstākas dabas resursu nodokḷa likmes (pelnu apstrādes izmaksas un maksa par piesārṇojušo vielu emisijām). Lìdz 2015.gadam kūdras izmantošanas izmaksas pieaugs no pusotra līdz divām reizēm (no 13,3 EUR / MWh kurināmā līdz 21,226,8 EUR / MWh kurināmā l), bet kurināmā izmaksas šķeldas gadījumā main̄isies nenozīmīgi. Dabasgāzei ir augsta cena, tādējādi kopējās degvielas izmantošanas izmaksas ir augstas. Tomēr, pateicoties zemam oglekḷa dioksīda emisijas koeficientam un nelielām pārējām ar vides piesārnošanu saistitām izmaksām, dabas gāze var samazināt savu kopējo izmaksu lielumu, salīdzot ar citiem fosilā kurināmā veidiem, kam ir lielāks oglekḷa dioksīda emisijas koeficients un arī augstākas citas ar vides piesārṇošanu saistîtās izmaksas.
\end{abstract}

Эдуард Латышов, Юри Клеэсмаа, Андрес Сиирде. Влияние природоохранных выплат, затрат на удаление золы и квот на выбросы СО, на конкурентоспособность топлива, используемого при производстве энергии в Эстонии

Целью данной статьи является определение влияния природоохранных выплат, затрат по удаление золы и квот на выбросы СО 2 (затраты связанные с охраной природы) на конкурентоспособность природного газа, сланца, торфа и древесной щепы в Эстонии по состоянию на 2010 и 2015 год. Государственная пошлина на выбросы загрязнителей атмосферы из стационарных источников загрязнения рассчитывается, исходя из Закона о Природоохранных Выплатах. Уровни загрязнения для рассматриваемых видов топлива определяются на основании Постановления №99/2004 и Постановления №94/2004 Министра окружающей среды Эстонии.

Проведённые расчеты показывают, что к 2015 году предполагаемое увеличение затрат связанных с охраной природы существенно изменит распорядок сил в ряду конкурентоспособности рассматриваемых видов топлива. В связи с высоким уровнем затрат, связанных с охраной природы, затраты связанные с использованием сланца (сумма затрат связанных с охраной природы и стоимости топлива на один МВтч нижней теплотворной способности топлива) существенно возрастёт (до двух раз). Это может стать критическим фактором, негативно влияющим на конкурентоспособность сланца с другими фоссильными и возобновляемыми топливами. В настоящее время торф рассматривается как хорошая альтернатива древесной щепе. Более низкая цена топлива $(11,7$ €/МВтч) по отношению к щепе (12,8 €/MВт/ч), уравновешивает более высокие затраты связанные с охраной природы (природоохранные выплаты и затраты на удаление золы). Но уже к 2015 году затраты, связанные с использованием торфа на один МВтч нижней теплотворной способности, составят от половины до двух раз (с 13,3 €/МВтч до 21,2-26,8 €/МВтч) . В то же самое время затраты на щепу останутся практически на прежнем уровне. Природный газ имеет высокой стоимости, которая составляет большую часть затрат, связанных с топливом. Но учитывая относительно низкий уровень выбросов углекислого газа, а также другие затраты, связанные с охраной природы, природный газ может уменьшить разрыв по части затрат на топливо в сравнении с другими видами фоссильного топлива, имеющими более высокий уровень эмиссий углекислого газа, и других затрат, связанных с охраной природы. 